\title{
Afscheid
}

\section{Fleur Imming}

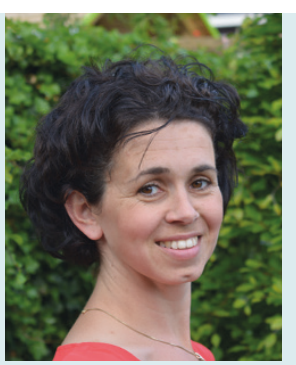

Afscheid, een thema dat onherroepelijk met palliatieve zorg verbonden is. Geconfronteerd worden met een levensbedreigende aandoening gaat gepaard met verlieservaringen. Stukje bij beetje moeten mensen vaak dingen loslaten die voor anderen zo vanzelfsprekend zijn. Als professional sta je naast deze mensen en ondersteun je ze in hun gevoelens van verdriet, boosheid en machteloosheid. Tijdens afscheid nemen komen gelukkig vaak ook mooie herinneringen naar boven. Zo herinner ik mij de gesprekken met een jonge man die mij op zijn sterfbed enthousiast vertelde over de marathons die hij gelopen had. Hij kon er zo gepassioneerd over vertellen dat hij mij aanmoedigde om ook te gaan hardlopen. Een andere man zag ik opnieuw genieten als hij mij vertelde over de campings die hij met zijn vrouw in zijn leven gerund had. Wat een mooie en verdrietige levensverhalen heb ik mogen horen op momenten dat het afscheid nabij was.

Ook in deze Pallium staat het thema afscheid centraal. Zo vertelt een kaderarts in haar column hoe zij afscheid neemt van een patiënt die ze nog van vroeger kent. In het drieluik besteden we aandacht aan het wel of niet opbaren in een hospice. Verder kunt u kennismaken met de gesprekshulp 'Oog in oog' voor het voeren van succesvolle levenseindegesprekken.

Met dit redactioneel 'Afscheid' neem ik afscheid van Pallium als redactielid. $\mathrm{Na} 10$ jaar is het voor mij tijd om dit mooie, multidisciplinaire vakblad los te laten. En dat afscheid is voor mij moeilijk, maar gaat gelukkig gepaard met hele mooie herinneringen.

Anke Clarijs- de Regt,

docent hbo-V en redacteur Pallium
11 oktober 2018 - 8th Amsterdam Symposium on Palliative Care

Met als thema: de laatste ontwikkelingen in symptoommanagement. Keynote-spreker is prof. Irene Higginson, hoogleraar en directeur van het Cicely Sauners Institute. www.vumc.nl.

\section{2 oktober 2018 - Congres Palliatieve zorg 2018}

Over het kwaliteitskader, ontwikkelingen en knelpunten, mantelzorg en existentiële vragen. www.verpleegkundigecongressen.nl.

18 oktober 2018 - Het levenseindegesprek met acute patiënten kan eerder!

Symposium in Amersfoort hoe je met de eerste en tweede lijn én de patiënt de wensen tijdig kenbaar maakt. www.scem.nl.

\section{4 oktober 2018 - Symposium} Op weg naar de toekomst

Nog betere Pijn- en Palliatieve Geneeskunde. Tevens afscheidssymposium van drie pioniers. www.radboudumc.nl.

\section{1 oktober 2018 - Zorg rondom het levenseinde}

Communicatie, emotie en humor staan centraal in dit congres voor verpleegkundigen en verzorgenden. www.congressenmetzorg.nl.

\section{6 november 2018 - De dokter en de dood}

Symposium 'De dokter en de dood' in Amsterdam. Sprekers zijn onder meer Bert Keizer en René ten Bos. www.medischcontactlive.nl.

\section{7 november 2018 - Landelijk symposium palliatieve zorg voor verzorgenden}

Thema is: van kwaliteitskader naar unieke patiënt. $w w w$.palliactief. $n l$.

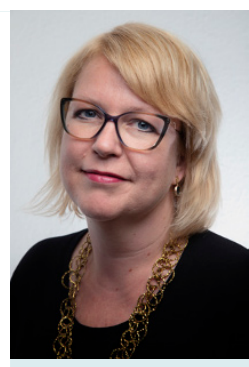

Vrijwilligers Palliatieve Terminale Zorg (VPTZ) Nederland heeft deze zomer een nieuwe directeur mogen verwelkomen. De voormalig Amersfoortse zorgwethouder Fleur Imming vertelt op haar tweede werkdag vanuit een zomers uitgestorven kantoor over haar nieuwe functie. "Vrijwilligers die mensen in de laatste levensfase begeleiden, daar heb ik heel veel bewondering voor."

Wat is uw affiniteit met de palliatieve zorg? "Ik heb veel affiniteit met de gezondheidszorg in algemene zin. Als wethouder had ik dit thema in mijn portefeuille en ik had veel contact met vrijwilligers in de zorg. Bij de VPTZ zijn elfduizend vrijwilligers aangesloten. Allemaal zijn ze intrinsiek zeer gemotiveerd om dit bijzondere werk te doen, het is toch anders dan wanneer je eens in de week een avond achter de bar staat bij een vereniging. Dit gegeven had de meeste aantrekkingskracht op mij."

\section{Welke ambities wilt u waarmaken?}

"De rol van de vrijwilliger begint anders te worden; wat over het algemeen een verzwaring van taken betekent. Beroepskrachten en vrijwilligers moeten vaker samenwerken en dat is een spannend proces. Ik wil een lans breken voor vrijwilligers in de terminale zorg, eraan werken dat professionals ze serieus nemen en energie steken in een goede samenwerking."

\section{Hoe kijkt $u$ aan tegen samenwerking met andere brancheorganisaties?}

"Als kersverse directeur die nog langs de zijlijn staat, vind ik meer intensieve samenwerking logisch. Er zijn best veel partijen actief waarmee ik graag het contact wil opzoeken, kijken waarin we elkaar kunnen versterken. Zeker ook als het gaat om de financiering van de palliatieve zorg. Als we willen dat er een nieuw, uniform en robuust bekostigingsmodel komt, dan moeten we stevig met elkaar optrekken.” 